\title{
Quantification of anaerobic digestion feedstocks for a regional bioeconomy
}

\author{
Robin Curry BSC, MSc, PhD \\ Lecturer, School of Chemistry and Chemical Engineering \\ Queen's University Belfast, Belfast, Northern Ireland, UK \\ (corresponding author: r.curry@qub.ac.uk)
}

María Natividad Pérez-Camacho MEng, MSc, PhD Research Fellow, School of Chemistry and Chemical Engineering, Queen's University Belfast, Belfast, Northern Ireland, UK

Robert Brennan BSC

Director, B9 Organic Energy Ltd, Larne, Northern Ireland, UK

\section{Stephen Gilkinson BA}

Research Scientist, Agri-Food and Biosciences Institute, Belfast, Northern Ireland, UK

Thomas Cromie BSC

Director, AgriAD Ltd, Banbridge, Northern Ireland, UK

Percy Foster BSC, MSC

Director, Cre Composting Association of Ireland, Enfield, Ireland

Beatrice Smyth MEng, PhD

Lecturer, School of Mechanical and Aerospace Engineering,

Queen's University Belfast, Belfast, Northern Ireland, UK

\section{Angela Orozco BEng}

Laboratory Supervisor, School of Chemistry and Chemical Engineering,

Queen's University Belfast, Belfast, Northern Ireland, UK

Elaine Groom BSC, PhD

NICP for the agri-food sector, Agri-Food and Biosciences Institute, Belfast, Northern Ireland, UK

Simon Murray MEng, PhD

Manager, Centre for Advanced Sustainable Energy (CASE), Belfast,

Northern Ireland, UK
Julie-Ann Hanna BEng, PhD

Manager, Questor Centre, Belfast, Northern Ireland, UK

Mark Kelly BSC, MSC

Director, MK Environmental, Lisburn, Northern Ireland, UK

Morgan Burke BSC, MSC

Development Manager, Stream BioEnergy, Blackrock, Ireland

Aaron Black BSC

Research Lecturer, South West College, Cookstown, Northern Ireland, UK

Christine Irvine BSC

Lecturer, South West College, Omagh, Northern Ireland, UK

David Rooney MEng, PhD

Professor, School of Chemistry and Chemical Engineering,

Queen's University Belfast, Belfast, Northern Ireland, UK

Steven Glover MEng, PhD

Lecturer, School of Mechanical and Aerospace Engineering,

Queen's University Belfast, Belfast, Northern Ireland, UK

Geoff McCullough MEng, PhD

Senior Lecturer, School of Mechanical and Aerospace Engineering,

Queen's University Belfast, Belfast, Northern Ireland, UK

Aoife Foley MEng, PhD

Lecturer, School of Mechanical and Aerospace Engineering,

Queen's University Belfast, Belfast, Northern Ireland, UK

Geraint Ellis BSc, MPhil, PhD, PGCHET, FHEA, FRSA

Professor, School of Natural and Built Environment, Queen's University Belfast, Belfast, Northern Ireland, UK

Anaerobic digestion (AD) for biogas production forms one of the fundamental building blocks of the bioeconomy, and a research programme has been under way in Northern Ireland, which culminated in the publication of a Biogas Research Action Plan 2020 in 2014. One important element of this programme was the identification of the need for an evidence base for the potential bioresource feedstocks. This paper reports the outputs of the quantification of feedstocks for AD research, which has identified the organic feedstocks available for biogas production on a regional basis and categorised these as: organic (biodegradable) fraction of municipal solid waste, sewage sludge, organic industrial and commercial wastes, manure from livestock, food wastes and energy crops. The research study further quantified the biogas and energy potential of these feedstocks and possible reductions in greenhouse gas emissions. The limitations of the research study are acknowledged and opportunities to address these and build on and extend the study are identified, including feedstocks for other bioeconomy processes and the application and further development of the biorefinery concept.

\section{Introduction}

The increasing interest in the circular economy and the growing evidence for its benefits in terms of material savings, emissions reduction and job creation (Mitchell and Doherty, 2015; Mitchell and Morgan, 2015), has led to a commensurate focus on the bioeconomy, particularly in those countries and regions with large agri-food sectors (Blades et al., 2017). The agri-food sector in Northern Ireland accounts for a higher proportion of the economy than the UK average, is the region's largest employer (Department for the Economy, 2017) and accounts for a much higher proportion of region's total greenhouse gas (GHG) emissions, at $29 \%$ as opposed to $9 \%$ in the rest of the UK (CCC, 2015). In addition, the sector has set ambitious growth targets to 2020 (growth of sales by $60 \%$ to $£ 7$ billion and sales outside Northern Ireland by 75\%), which will result in a commensurate growth in wastes from this sector 
(AFSB, 2013). Anaerobic digestion (AD) has been proposed by several researchers and policymakers as central to reducing emissions of GHGs from agriculture and food production (Bacenetti et al., 2016; Kaparaju and Rintala, 2011), waste management (Davidsson et al., 2007) and as a source of renewable energy (Curry and Pillay, 2012) and/or biofuels (Börjesson and Mattiasson, 2008; Singh et al., 2010).

In response to these drivers and challenges, a programme of research has been ongoing in Northern Ireland with the aim of defining priorities for support to regional development, co-operation and knowledge transfer within the region in the field of production and use of biogas, in order to realise the following objectives (Groom and Orozco, 2014).

- Development of new cost-effective, energy-efficient and sustainable technologies for biogas production and use within energy supply chains.

- Development of technologies and services optimising the benefits of biogas for Northern Ireland agriculture, infrastructure and communities.

- Provision of research expertise and facilities for manufacturers to commercialise ideas from research and development activities.

The authors report one of the main outputs of this research, namely the quantification of feedstocks for AD. The need for classification and quantification of feedstocks is widely recognised by researchers and policymakers as essential to planning and implementation in all areas of waste and resource management (Thomas, 2004), and particularly for the information needs of the bioeconomy (HLEUC, 2014). This research study has identified the organic feedstocks available for biogas production on a regional basis and categorised them.

AD offers significant benefits in the context of bioeconomy, including (Monson et al., 2007)

- recycling nutrients and organic matter (digestate) back to land (subject to legislative constraints) and reducing the consumption of chemical fertilisers

reduction of GHG emissions

- diverting biodegradable municipal waste away from landfill

- generation of renewable energy

- creation of jobs in the supply chain

- heat capture and use in heating schemes - for example, commercial operations and district heating schemes

- upgrading biogas (biomethane) to be used as a biofuel for vehicles - for example, road freight, agricultural and similar plant and machinery

- upgrading biogas (biomethane) to natural gas quality for injection into the gas grid.

\section{Methodology}

The research focused on the theoretical estimates of the organic resources generated and potentially available, based on the methodology set out by Slade et al. (2011), who described how biomass potential estimates are most often discussed in terms of a 'hierarchy of opportunity' - theoretical, technical, economic and realistic - as illustrated in Figure 1.

The scope of this study was to focus on the theoretical estimates of the organic resources generated and potentially available within Northern Ireland for AD and their biogas production potential. Organic resources potentially available as $\mathrm{AD}$ feedstocks are set out below and classified in Figure 2.

- Organic (biodegradable) fraction of municipal solid waste (OFMSW).

- Sewage sludge.

- Organic industrial and commercial wastes - that is, food/beverage/tobacco processing wastes, slaughterhouse/rendering wastes, dairy wastes.

- Manure from livestock.

- Food wastes from households (separately collected/source segregated), catering, restaurants, hotels.

\section{Results}

\subsection{Municipal and commercial and industrial organic waste arisings}

Data on waste arisings for municipal and commercial and industrial (C\&I) wastes have improved significantly in recent years. In particular for municipal wastes, the introduction of the WasteDataFlow web-based system for municipal waste data reporting has enabled faster and more accurate data collection of municipal waste statistics (WDF, 2017). The

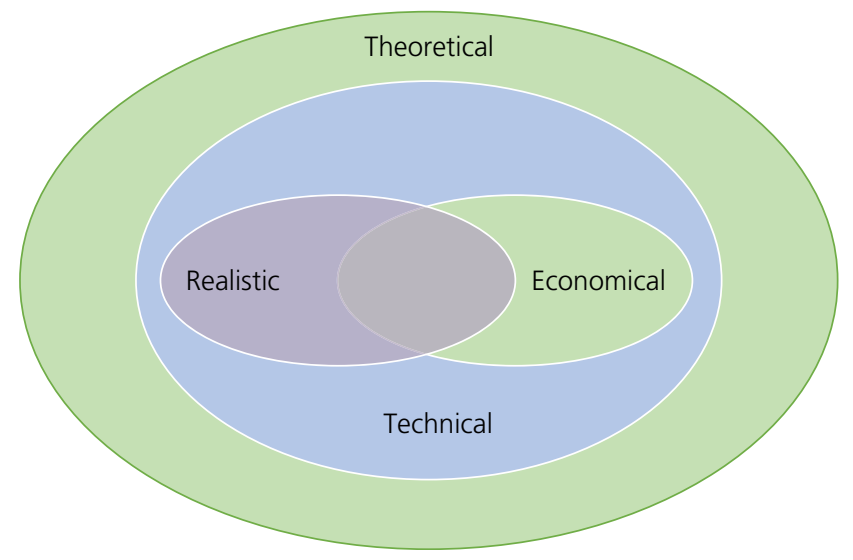

Figure 1. Hierarchy of feedstocks and energy potential for organic resources for $A D$ 


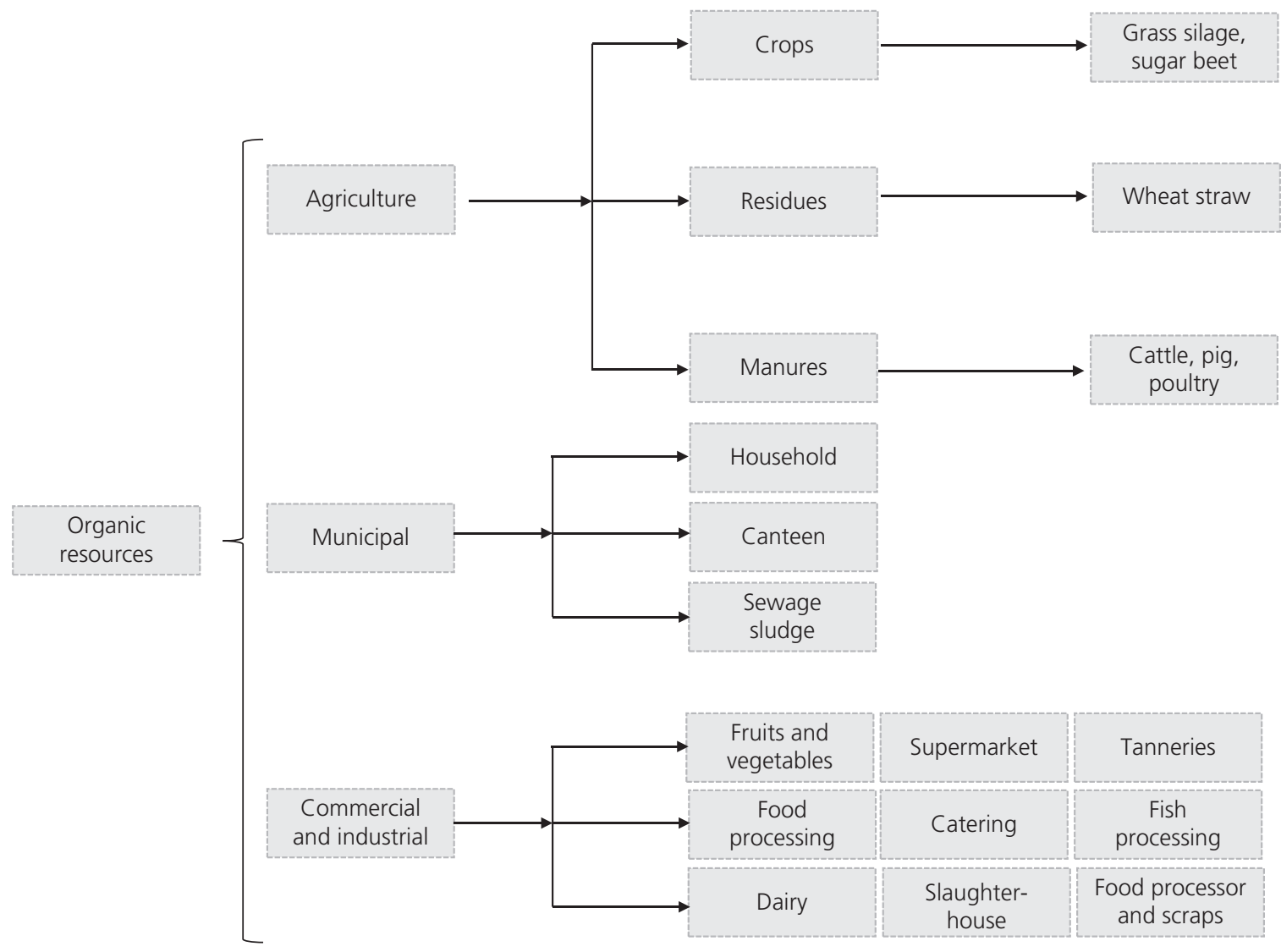

Figure 2. Classification of feedstocks potentially available for AD in Northern Ireland (source: reproduced from Groom and Orozco (2014))

accuracy of the data on C\&I waste has also improved, with a number of national C\&I waste arisings studies being carried out in England and Wales, Scotland and Northern Ireland over the last 10 years.

Across the period 2002-2013, reported municipal waste recycling and composting rates in Northern Ireland increased from approximately $9 \%$ to approximately $45 \%$. The baseline year for the study was the 2012-2013 reporting year and the Northern Ireland Local Authority Collected Municipal Waste Management Statistics Annual Report 2012/13 (Burgess, 2013) reported that the total local authority collected municipal waste (LACMW) arisings were $913546 \mathrm{t}$ (the statistics have subsequently been updated for the years 2014/2015 and 2015/2016, and recommendations on updating have been included in discussion and conclusions). Of this amount, $91216 \mathrm{t}$ of municipal compostable waste excluding all wood, was collected at the kerbside and $59555 \mathrm{t}$ collected at civic amenity sites (150 $772 \mathrm{t}$ total) with $142798 \mathrm{t}$ (or 15.6\%), reported as being composted.
The total household waste arisings (2012/2013) were $803624 \mathrm{t}$, with $141428 \mathrm{t}$ (or $17 \cdot 6 \%$, excluding all wood) reported as being composted.

- The estimated available compostable material, as household kerbside collected waste, was $239418 \mathrm{t}$. Of this quantity, $90938 \mathrm{t}$ (37.9\%) was captured in the 2012-2013 period, meaning that $148480 \mathrm{t}$ or $62 \cdot 1 \%$ of compostable material was not captured in household kerbside separate collections.

- An amount of $276702 \mathrm{t}$ of biodegradable local authority collected municipal waste (BLACMW) was sent to landfill.

The Food Waste Regulations (Northern Ireland) 2015 (HMG, 2015) set out the following.

- Require food waste producers to present food waste for separate collection.

- Introduce an obligation on district councils to provide receptacles for the separate collection of household food waste. 
- Introduce a ban on mixing separately collected food waste

- Introduce a ban on the landfilling of separately collected food waste.

- Introduce a ban on the non-domestic discharge of food waste into the public sewer network.

The Partial Regulatory Impact Assessment (RIA) (DoENI, 2013) completed for the above regulations estimated

- the food waste collected by councils for the period 2011/2012, to be $12820 \mathrm{t}$ (comprising $12113 \mathrm{t}$ co-mingled and $707 \mathrm{t}$ from separately collected food waste)

- the (indicative modelled) estimate of food waste that could be diverted from landfill if councils were to offer a separate food waste or co-mingled collection service as $79960 \mathrm{t}$ per annum (tpa), comprising 21119 tpa from co-mingled collections and 58841 tpa (maximum 59062 tpa, minimum 58619 tpa) from separate collections.

The RIA also provided figures for non-domestic food waste arising in Northern Ireland. In the lack of specific data for Northern Ireland, these were based on the assumption that commercial food waste composition and arisings in the UK were broadly indicative of that in Northern Ireland pro rata. The most reliable figures available to the Department of the Environment when preparing the RIA were the Waste and Resource Action Programme's (Wrap) Tackling Priority Materials in Northern Ireland report (Wrap, 2012), which suggested (indicatively) that for 2009, of Northern Ireland's
1.3 million t C\&I waste arisings, approximately $150000 \mathrm{t}$ was food waste, managed as follows

- $36443 \mathrm{t}$ (in residual waste) disposed to landfill

- $34935 \mathrm{t}$ other

- $15441 \mathrm{t}$ reused

- $61579 \mathrm{t}$ recycled/composted.

The Northern Ireland Organic Energy Study (OES) report, published by Invest NI (Nicholl $\mathrm{C}$ and Smyth G, personal communication, 2010), reviewed the magnitude and extent of organic and food waste arisings in Northern Ireland. The information and data were collected by using a combination of methods including engagement with a range of public and private sector organisations, interviews and a survey of all companies of significant magnitude operating in the range of commercial and industrial sectors within Northern Ireland.

The final report referenced is the Southern Waste Management Partnership (Swamp) Waste Management Plan (Swamp, 2013), which provides its estimates for the quantities of municipal and C\&I organic/biowaste generated within the south-west region of Northern Ireland and also Northern Ireland as a whole. There is a wide variation in the final total organic/biowaste arisings estimates, possibly as a result of differing methods or classification systems, which requires further investigation (Table 1).

\section{Manures}

Agricultural manures were previously excluded from regulations that controlled the management of household, C\&I

Table 1. Northern Ireland organic/biowaste arisings

\begin{tabular}{|c|c|c|c|c|}
\hline \multirow{2}{*}{$\begin{array}{l}\text { Waste } \\
\text { Data source }\end{array}$} & \multicolumn{3}{|c|}{ Quantity: t/year } & \multirow[b]{2}{*}{ Current management } \\
\hline & $\mathrm{OES}^{\mathrm{a}}$ & Wrap ${ }^{b}$ & Swamp ${ }^{c}$ & \\
\hline \multicolumn{5}{|l|}{ Municipal } \\
\hline Household & 188000 & 381320 & 162811 & Composting, landfill \\
\hline Sewage sludge (dry) & 39000 & 37700 & 39000 & Incineration \\
\hline Total municipal & 227000 & 419020 & 201811 & Average municipal=282 610 \\
\hline \multicolumn{5}{|l|}{ C\&l } \\
\hline Retail food & 35700 & & & Composting, pet food, returned to original supplier \\
\hline Catering & 4140 & & & Composting, landfill, to drain sewer \\
\hline Food processing & 26000 & & & Composting, landfill, animal feed \\
\hline Slaughterhouse & 178230 & & & Land spreading, rendering, animal food \\
\hline Dairy & 13200 & & & Land spreading, landfill, animal feed \\
\hline Drinks and distillery & 12000 & & & Animal feed \\
\hline Animal and vegetable waste & & & 145573 & Composting, landfill, animal feed \\
\hline Green and food waste & & 189150 & & Composting, landfill, animal feed \\
\hline Total C\&l & 269270 & 189150 & 145573 & Average C\&I=201331 \\
\hline Total organic waste & 496270 & 608170 & 347384 & Average total = 483941 \\
\hline
\end{tabular}

${ }^{a}$ Nicholl and Smyth, personal communication

bWrap (2012)

'Swamp (2013) 
waste. The implementation of The Waste Management Regulations (Northern Ireland) 2006 (HMG, 2006), as amended, has however resulted in waste management controls applying to agricultural manures in accordance with the European Waste Framework and Landfill Directives (EC, 1999, 2008).

Table 2 shows that approximately $10 \cdot 8$ million $t$ of manure are produced in Northern Ireland per year. The manures considered are cattle, pig and poultry. For cattle it was assumed that they are kept indoors for 6 months. Cattle manure is the main contributor to the total manure available in Northern Ireland. It is important to note that the 'animal units' in Table 2 can vary within a year, and numbers present may not be counted for the full year in the agricultural census. This is especially true for poultry units, due to the short life span for broiler chickens (about 5-8 weeks).

\section{Agricultural crops}

According to analysis by Goulding and Power (2013), biogas produced from grass silage can make a significant contribution to electrical and thermal energy production in the Republic of Ireland, with no negative effect on food production. Most agricultural land in Northern Ireland is under grass, as grass is the main feedstock of the ruminant livestock sectors - beef, dairy and sheep. An area of 0.78 Mha (excluding hill and rough land) is utilised for growing grass and clover in Northern Ireland. Much of the land under grass is unsuitable for alternative arable use, due to the topography and climatic conditions (Sharma et al., 2011). If 5\% of the grassland area in Northern Ireland was dedicated to grass silage production for AD (39 000 ha), the electrical output from this would be 1326 GWh (Smyth et al., 2009).

Reasons for using grass to produce renewable energy in Northern Ireland include the following.

- Ninety-two per cent of agricultural land in Northern Ireland is under grass.

- Grass/silage yields on the island of Ireland are among the highest in Western Europe (Smyth et al., 2009).

- The production of renewable energy (as biogas) from grass requires no major changes in agricultural practice and

Table 2. Manure produced in Northern Ireland from housed livestock

\begin{tabular}{ll} 
Animal sector & Approximated manure: $\mathbf{t} / \mathbf{y e a r}$ \\
\hline Cattle & 10 million \\
Pig & 500000 \\
Poultry & 300000 \\
Total & $10 \cdot 8$ million \\
\hline
\end{tabular}

would provide an additional option to farmers for income generation.

- Agriculture accounted for $26 \%$ of Northern Ireland's GHG emissions in 2010 (CCC, 2015). AD is a proven method for mitigating GHG emissions from agricultural production (Kaparaju and Rintala, 2011).

- In 2010, $96 \%$ of fuel used in Northern Ireland was imported and the vast majority of this was from fossil sources (Department for the Economy, 2017). AD has the potential to reduce this dependence on fossil fuel.

- Biomethane production from grass is one of the most sustainable indigenous, non-residue-based European transport fuels in terms of GHG emissions (Murphy and Power, 2009).

\section{Biogas and energy potential}

Table 3 shows the theoretical estimates of biogas potential of different materials used as feedstocks for AD.

\section{Potential biogas, biomethane and energy production from waste and grass silage in Northern Ireland}

Table 4 shows that the estimates of the potential of electricity and heat production from wastes streams and grass silage is in the range 458-2020 $\mathrm{GWh}_{\mathrm{e}}$ and $655-2885 \mathrm{GWh}_{\mathrm{h}}$, respectively. It is important to note that these figures are the theoretical maximum potential (as explained in Figure 1). The figures in Table 4 do not include parasitic demands in the AD process. It is assumed that the $\mathrm{AD}$ process of an installed electrical power of $500 \mathrm{~kW}_{\mathrm{e}}$ digesting crops only utilises $4 \%$ of electricity and $17 \%$ of heat (Weiland, 2010). The additional electricity requirement for upgrading was assumed to be $0 \cdot 2 \mathrm{kWh}$ per $\mathrm{N} \mathrm{m}^{3}$ of biogas, based on water scrubbing. A review of a range of sources for the energetic requirements of biogas upgrading technologies suggested the energy requirements could potentially be much higher and the discussion and conclusions included a recommendation for a sensitivity analysis to evaluate the impacts of key assumptions on the estimates for the energetic requirements of biogas upgrading (Patterson et al., 2011).

\section{Reduction in GHGs}

While the primary aim of the research was the quantification of feedstocks, the project did attempt to provide an estimate of the potential reductions in GHG emissions associated with the generation of energy and heat from the AD of the feedstocks. Table 5 sets out the potential for GHG emissions reduction from the replacement of fossil fuels with biogas, relative to grid electricity. 
Table 3. Biogas potential of different materials used as feedstocks for AD

\begin{tabular}{|c|c|c|c|c|c|c|c|c|c|}
\hline Waste category & $\begin{array}{l}\text { Waste amount: } \\
\text { t/year }\end{array}$ & TS: \% & $\begin{array}{c}\text { VS: } \% \text { of } \\
\text { TS }\end{array}$ & $\begin{array}{c}\text { Methane } \\
\left(\mathrm{CH}_{4}\right) \text { yield: } \\
\mathrm{m}^{3} \mathrm{~N} \mathrm{CH}_{4} / \mathrm{t} \text { VS }\end{array}$ & $\begin{array}{l}\text { Methane yield } \\
\text { average: } \\
\mathrm{m}^{3} \mathrm{~N} \mathrm{CH}_{4} / \mathrm{t} \text { VS }\end{array}$ & $\begin{array}{l}\text { Methane } \\
\text { content: \% }\end{array}$ & $\begin{array}{c}\text { Methane content } \\
\text { average: } \%\end{array}$ & $\begin{array}{l}\text { Biogas: } \\
\mathrm{m}^{3} / \text { year }\end{array}$ & $\begin{array}{l}\text { Methane: } \\
\mathrm{m}^{3} \text { /year }\end{array}$ \\
\hline Household $^{a}$ & 244043 & 10 & 80 & $350-480$ & 415 & $70-80$ & 75 & 10802999 & 8102249 \\
\hline $\begin{array}{l}\text { Sewage sludge } \\
(2-5 \% \text { VS })^{\mathrm{b}}\end{array}$ & 38566 & $2 \cdot 5$ & 65 & $140-210$ & 175 & 60 & 60 & 182789 & 109673 \\
\hline Retail food ${ }^{c}$ & 35700 & 36 & $66 \cdot 5$ & $200-440$ & 320 & 60 & 60 & 4558176 & 2734905 \\
\hline Catering $^{d}$ & 4140 & 29 & 95 & $467-529$ & 498 & 60 & 60 & 946673 & 568003 \\
\hline Food processing ${ }^{e}$ & 26000 & 15 & 80 & $276-738$ & 507 & 60 & 60 & 2636400 & 1581840 \\
\hline Slaughterhouse $\mathrm{e}^{f}$ & 178230 & 10 & 77 & $400-610$ & 505 & 60 & 60 & 11550789 & 6930473 \\
\hline Dairy ${ }^{9}$ & 13200 & $31 \cdot 5$ & 89.5 & $455-708$ & $581 \cdot 5$ & $60-80$ & 70 & 3091428 & 2163999 \\
\hline Drinks and distillery ${ }^{g}$ & 12000 & 5 & 91 & $335-385$ & 360 & 60 & 60 & 327600 & 196560 \\
\hline Dairy cattle manure & 10000000 & 8.5 & 80 & $110-240$ & 175 & $55-75$ & 65 & 183076923 & 119000000 \\
\hline Pig manure $\mathrm{e}^{\mathrm{a}}$ & 500000 & 5.5 & 80 & $175-400$ & $287 \cdot 5$ & $70-80$ & 75 & 8433333 & 6325000 \\
\hline Chicken manure $\mathrm{e}^{\mathrm{e}}$ & 300000 & 20 & 80 & $210-480$ & 345 & $60-80$ & 70 & 23657142 & 16560000 \\
\hline \multirow[t]{3}{*}{ Grass silage $^{\mathrm{h}}$} & 1937170 & 20 & 91 & $341-483$ & 412 & 60 & 60 & 242094606 & 145256763 \\
\hline & & & & & & & Total & 491358862 & 309529470 \\
\hline & & & & & & & Approximation & 491 million & 309 million \\
\hline
\end{tabular}

TS, total solids; VS, volatile solids

aZhang et al. (2014)

bitk et al. (2013)

'Alkanok et al. (2014)

dBrowne and Murphy (2013)

eSteffen et al. (1998)

${ }^{\mathrm{f}}$ Karlsson and Ejlertsson (2012)

'Luna-del Risco et al. (2011)

${ }^{\text {h}}$ Nizami et al. (2012) 
Table 4. Potential biomethane and energy production from waste and grass silage in Northern Ireland

\begin{tabular}{|c|c|c|c|c|}
\hline Feedstock & $\begin{array}{l}\text { Biomethane }{ }^{\mathrm{a}} \text { : million } \mathrm{m}^{3} \mathrm{~N} \\
\mathrm{CH}_{4} / \text { year }\end{array}$ & $\begin{array}{l}\text { Gross energy } \\
\text { TJ/year }\end{array}$ & $\begin{array}{l}\text { Electrical energyc: } \\
\text { GWh } \mathrm{h}_{\mathrm{e}} / \text { year }\end{array}$ & $\begin{array}{l}\text { Heat energyc: } \\
\text { GWh }_{h} / \text { year }\end{array}$ \\
\hline \multicolumn{5}{|l|}{ Organic waste } \\
\hline Total municipal & $5-15$ & $164-529$ & $16-51$ & $23-74$ \\
\hline Total C\&I & $4-22$ & 159-786 & $15-76$ & 22-109 \\
\hline $\begin{array}{l}\text { Total organic } \\
\text { waste }\end{array}$ & $9-37$ & 324-1315 & $31-128$ & $45-183$ \\
\hline \multicolumn{5}{|l|}{ Agricultural } \\
\hline Cattle manure & $41-261$ & $1455-9253$ & $142-900$ & $202-1286$ \\
\hline Pig manure & $2-5$ & 68-178 & 7-17 & $9-25$ \\
\hline Poultry manure & $4-35$ & $157-1227$ & 15-119 & $22-171$ \\
\hline Total manure & $47-300$ & $1680-10658$ & 163-1037 & 233-1481 \\
\hline Grass silage & $76-247$ & $2706-8785$ & $263-855$ & $376-1221$ \\
\hline Total potential & $133-585$ & 4709-20 758 & $485-2020$ & $655-2885$ \\
\hline
\end{tabular}

aYiridoe et al. (2009)

${ }^{\mathrm{b}}$ Monson et al. (2007)

cMurphy and Power (2009)

Table 5. Potential for GHG emissions reduction from the replacement of fossil fuels with biogas

\begin{tabular}{lccc} 
Feedstock & Quantity: t/year & $\begin{array}{c}\text { Biogas production average: } \\
\text { million } \mathbf{~ m}^{\mathbf{3}} \text { /year }\end{array}$ & $\begin{array}{c}\text { Carbon dioxide reduction with CHP production: } \\
\text { optimal use } \mathbf{a}^{\text {: }} \text { t carbon dioxide/year }\end{array}$ \\
\hline Total organic wastes & 421827 & 23 & 76927 \\
Total manure & 10800000 & 174 & 579223 \\
Grass silage & 1901250 & 162 & 539475 \\
Total & 13791995 & 359 & 195626
\end{tabular}

ahiting and Azapagic (2014)

\section{Digestate production and use}

While the focus of $\mathrm{AD}$ has traditionally been biogas production and utilisation, circular and bioeconomy processes are leading to increased emphasis on the digestate outputs from the AD process, which account for approximately $90 \%$ of the outputs by weight (Tampio et al., 2016). One interesting approach is to place AD within the anaerobic biorefinery concept, to allow for an integrated approach, which maximises synergies between them (Sawatdeenarunat et al., 2016). The use of the anaerobic biorefinery concept allows the evaluation of both energy (electricity and heat) and chemical/material/ nutrients management pathways in an integrated way and can contribute to the development of a roadmap for a regional bioeconomy (Vazquez-Rowe et al., 2015). While digestate utilisation was not part of the original aims of the quantification of feedstocks project, the authors have submitted a companion paper (Pérez-Camacho and Curry, 2018), which applies the anaerobic biorefinery concept to the feedstock estimates generated by this research study, to identify utilisation options for the digestate outputs from the $\mathrm{AD}$ process using the anaerobic biorefinery concept.

\section{Discussion and conclusions}

This research investigation has enhanced understanding of potential feedstocks for AD in Northern Ireland and contributed to the development of an evidence base for the planning and implementation of a regional bioeconomy. While the investigation was developed based on the Northern Ireland region, the issues identified and discussed in this paper can provide insights for other projects on the bioeconomy potential at regional or sub-national level and help set out the priorities for research to support this important policy area. The outputs of the project have provided a snapshot of the potentially available AD feedstocks and estimated the quantities of wastes available for $\mathrm{AD}$, which has the potential to benefit the regional bioeconomy significantly.

An important limitation of the research is the data and assumptions used to progress from waste flows to estimates of biogas production and ultimately to total potential electricity production. In terms of waste quantities, the baseline year for the project was 2013/2014 (this was required to ensure compatibility of the quantification of feedstocks with other 
elements of the research programme) and it recommended that these data be updated. Additionally, a sensitivity analysis of key assumptions (such as biogas yield, parasitic loads, biogas upgrading energy requirements etc.) would allow the identification of future research priorities in this rapidly developing field.

One other important limitation of the research, within the context of the rapidly evolving concept of the bioeconomy, was its focus on feedstocks for AD. In recent years, the concept of the bioeconomy has further developed to include, in addition to biochemical processes such as $\mathrm{AD}$, thermochemical processes, such as pyrolysis and gasification (producing syngas and biochar), and catalytic or enzymatic processes, such as fermentation. This evolution of the bioeconomy concept has the potential not only to increase significantly the range and quantity of feedstocks but also to enable the production of higher added-value products, thus contributing to the economic sustainability of the bioeconomy. A seminal report on the bioeconomy by the UK House of Lords, categorised feedstocks based on relative ease of access to carbon, and emphasised the challenge of ensuring that the 'feedstock-processproduct combination represents an economically and environmentally viable proposition' (HLEUC, 2014: p. 13). The report identified the following process/sub-process categories for the bioeconomy.

- Thermochemical: pyrolysis, gasification.

- Chemical: catalytic processes, esterification.

- Bioprocessing: enzymatic processes; fermentation; biocatalysis; aerobic conversion (composting); AD.

Clearly, investigating the full range of process/sub-process categories allows for the identification of a wider range of feedstocks and product outputs and can allow the identification of potential synergies between these feedstock-processproduct flows. Sawatdeenarunat et al. (2016) have identified the anaerobic biorefinery concept as a promising new approach for producing biobased products, with the potential to maximise potential economic benefits, and one potentially valuable area of further research is to apply the anaerobic biorefinery concept developed to the full range of process/sub-process categories for the bioeconomy. This identifies a number of interesting and important priorities for ongoing research, including

- feedstock evaluation - future evaluations should attempt, as far as possible, to identify the full range of potential feedstocks for the bioeconomy

- anaerobic biorefinery - further development of the anaerobic biorefinery approach by way of its application to the full range of process/sub-process categories for the bioeconomy.
The authors hope that the issues identified and discussed in this paper can provide insights for other researchers and help set out the priorities for future research.

\section{Acknowledgements}

This project was carried out by the QUESTOR centre at Queen's University Belfast and was part financed through Invest NI by the European Regional Development Fund under the European Sustainable Competitiveness Programme for Northern Ireland. Both Dr Elaine Groom and Dr Angela Orozco have been staff at QUESTOR when this project was undertaken. This paper was then prepared as part of the 'Biogas to Biorefinery' project to raise awareness about biogas in NI. The 'Biogas to Biorefinery' project was funded by the Centre for Advanced Sustainable Energy (CASE) through the Invest NI Northern Ireland Competence Centre programme, which bridges the gap between industry research needs and academic research offerings.

\section{REFERENCES}

AFSB (Agri-Food Strategy Board) (2013) Going for Growth - a Strategic Action Plan in Support of the NI Agri-Food Sector. AFSB, Belfast, UK. See http://www.agrifoodstrategyboard.org.uk/uploads/Going $\% 20$ for $\% 20$ Growth $\% 20-\% 20$ Web $\% 20$ Version.PDF (accessed 06/03/2017)

Alkanok G, Demirel B and Onay T (2014) Determination of biogas generation potential as a renewable energy source from supermarket wastes. Waste Management 34(1): 134-140.

Bacenetti J, Bava L, Zucali M et al. (2016) Anaerobic digestion and milking frequency as mitigation strategies of the environmental burden in the milk production system. Science of the Total Environment 539: 450-459, https://doi.org/10.1016/j.scitotenv.2015. 09.015 .

Blades L, Morgana K, Douglas R et al. (2017) Circular biogas-based economy in a rural agricultural setting. Energy Procedia 123: 89-96.

Börjesson P and Mattiasson B (2008) Biogas as a resource-efficient vehicle fuel. Trends in Biotechnology 26(1): 7-13, https://doi.org/ 10.1016/j.tibtech.2007.09.007.

Browne J and Murphy J (2013) Assessment of the resource associated with biomethane from food waste. Applied Energy 104(0): 170-177.

Burgess K (2013) Northern Ireland Local Authority Collected Municipal Waste Management Statistics Annual Report 2012/13. Department of the Environment, Belfast, UK. See https://www.daera-ni.gov.uk/ sites/default/files/publications/doe/lac-municipal-waste-2012-13.pdf (accessed 12/11/2018)

CCC (Committee on Climate Change) (2015) The Appropriateness of a Northern Ireland Climate Change Act-December 2015 Update. CCC, London, UK. See https://www.theccc.org.uk/wpcontent/uploads/2016/01/CCC-2015-update-to-the-appropriatenessof-a-Northern-Ireland-Climate-Change-Act.pdf (accessed 06/03/2017)

Curry N and Pillay P (2012) Biogas prediction and design of a food waste to energy system for the urban environment. Renewable Energy 41: 200-209, https://doi.org/10.1016/ j.renene.2011.10.019.

Davidsson $\AA$, la Cour Jansen J, Appelqvist B, Gruvberger C and Hallmer M (2007) Anaerobic digestion potential of urban organic waste: a 
case study in Malmö. Waste Management \& Research 25(2): 162-169, https://doi.org/10.1177/0734242x07075635.

Department for the Economy (2017) A Consultation on an Industrial Strategy for Northern Ireland. Economy 2030. Department for the Economy, Belfast, UK. See https://www.economy-ni.gov.uk/ consultations/industrial-strategy (accessed 06/03/2017).

DoENI (Department of the Environment for Northern Ireland) (2013) Partial Regulatory Impact Assessment. DoENI, Belfast, UK. See https://www.ifsa.eu.com/uploads/1/2/0/2/120245019/ria_document_ ni_partial_regulatory_impact_assessment__assumptions_ for_i...pdf (accessed 06/03/2017).

EC (European Community) (1999) Council Directive 1999/31/EC of 26 April 1999 on the landfill of waste. Official Journal of the European Communities L182/1.

EC (2008) Directive 2008/98/EC of the European Parliament and of the Council of 19 November 2008 on waste and repealing certain Directives. Official Journal of the European Communities L312/3.

Goulding D and Power N (2013) Which is the preferable biogas utilisation technology for anaerobic digestion of agricultural crops in Ireland: biogas to CHP or biomethane as a transport fuel? Renewable Energy 53: 121-131, https://doi.org/10.1016/ j.renene.2012.11.001.

Groom E and Orozco A (2014) Northern Ireland Biogas Research Action Plan 2020. Queen's University Belfast, Belfast, UK.

See http://questor.qub.ac.uk/GeneralFileStorenew/DO-Bioenergy/ Filetoupload,465991,en.pdf (accessed 06/03/2017).

HLEUC (House of Lords European Union Committee) (2014) Waste Opportunities: Stimulating a Bioeconomy. HLEUC, London, UK. See http://www.parliament.uk/business/committees/committees-az/lords-select/science-and-technologycommittee/inquiries/parliament-2010/waste-and-bioeconomy/ (accessed 06/03/2017)

HMG (Her Majesty's Government) (2006) The Waste Management Regulations (Northern Ireland) 2006. The Stationery Office, Belfast, UK, Statutory Rule of Northern Ireland 2006 No. 280.

HMG (2015) The Food Waste Regulations (Northern Ireland) 2015. The Stationery Office, Belfast, UK, Statutory Rule of Northern Ireland 2015 No. 14.

Kaparaju P and Rintala J (2011) Mitigation of greenhouse gas emissions by adopting anaerobic digestion technology on dairy, sow and pig farms in Finland. Renewable Energy 36(1): 31-41, https://doi.org/ 10.1016/j.renene.2010.05.016

Karlsson A and Ejlertsson J (2012) Addition of $\mathrm{HCl}$ as a means to improve biogas production from protein-rich food industry waste. Biochemical Engineering Journal 61: 43-48.

Luna-del Risco M, Normak A and Orupõld K (2011) Biochemical methane potential of different organic wastes and energy crops from Estonia. Agronomy Research 9(1-2): 331-334.

Mitchell P and Doherty M (2015) Job Creation in the Circular Economy - Increasing Resource Efficiency in Northern Ireland. Wrap, Belfast, UK. See https:/www.crni.ie/wp-content/uploads/ 2017/02/renew_ce_employment_report.pdf (accessed 08/11/2018).

Mitchell P and Morgan J (2015) Employment and the Circular Economy Job Creation in a More Resource Efficient Britain. Green Alliance, London, UK. See https://www.green-alliance.org.uk/employmentand-the-circular-economy.php (accessed 08/11/2018).

Monson K, Esteves S, Guwy A and Dinsdale R (2007) Anaerobic Digestion of Biodegradable Municipal Wastes: A Review. University of Glamorgan, Pontypridd, UK. See https://www.walesadcentre.org uk/media/1050/anaerobic-digestion-of-bmw-_compressed_-part1. pdf (accessed 06/03/2017)

Murphy JD and Power NM (2009) An argument for using biomethane generated from grass as a biofuel in Ireland. Biomass and
Bioenergy 33(3): 504-512, https://doi.org/10.1016/j.biombioe. 2008.08.018

Nizami A, Orozco A, Groom E, Dieterich B and Murphy J (2012)

How much gas can we get from grass? Applied Energy

92: 783-790

Patterson T, Esteves S, Dinsdale R and Guwy A (2011) An evaluation of the policy and techno-economic factors affecting the potential for biogas upgrading for transport fuel use in the UK. Energy Policy 39(3): 1806-1816.

Pérez-Camacho MN and Curry R (2018) Regional assessment of bioeconomy options using the anaerobic biorefinery concept. Proceedings of the Institution of Civil Engineers - Waste and Resource Management, https://doi.org/10.1680/jwarm.17.00015.

Pitk P, Kaparaju P, Palatsi J, Affes R and Vilu R (2013) Co-digestion of sewage sludge and sterilized solid slaughterhouse waste: methane production efficiency and process limitations. Bioresource Technology 134: 227-232.

Sawatdeenarunat C, Nguyen D, Surendra K et al. (2016) Anaerobic biorefinery: current status, challenges, and opportunities. Bioresource Technology 215: 304-313, https://doi.org/10.1016/ j.biortech.2016.03.074

Sharma HSS, Lyons G and McRoberts C (2011) Biorefining of perennial grasses: a potential sustainable option for Northern Ireland grassland production. Chemical Engineering Research and Design 89(11): 2309-2321, https://doi.org/10.1016/ j.cherd.2011.03.004.

Singh A, Smyth BM and Murphy JD (2010) A biofuel strategy for Ireland with an emphasis on production of biomethane and minimization of land-take. Renewable and Sustainable Energy Reviews 14(1): 277-288, https://doi.org/10.1016/ j.rser.2009.07.004

Slade R, Saunders R, Gross R and Bauen A (2011) Energy from Biomass: the Size of The Global Resource An Assessment of The Evidence That Biomass Can Make a Major Contribution to Future Global Energy Supply. UK Energy Research Centre, London, UK. See http://www.ukerc.ac.uk/publications/energy-from-biomass-the-sizeof-the-global-resource.html (accessed 06/03/2017).

Smyth B, Murphy J and O'Brien C (2009) What is the energy balance of grass biomethane in Ireland and other temperate northern European climates? Renewable and Sustainable Energy Reviews 13(9): 2349-2360, https://doi.org/10.1016/ j.rser.2009.04.003.

Steffen R, Szolar O and Braun R (1998) Feedstocks for Anaerobic Digestion. University of Agricultural Sciences, Vienna, Austria. See https://pdfs.semanticscholar.org/293e/ a2a9a8d8315548b8d749f60e4b28378d9dfa.pdf (accessed 06/03/2017).

Swamp (Southern Waste Management Partnership) (2013) Waste Management Plan. Draft for Consultation. May 2013. Department of the Environment for Northern Ireland, Belfast, UK. See http://www.newryandmourne.org.uk/documents/ DraftforConsultation-May2013.pdf (accessed 15/01/2017).

Tampio E, Marttinen S and Rintala J (2016) Liquid fertilizer products from anaerobic digestion of food waste: mass, nutrient and energy balance of four digestate liquid treatment systems. Journal of Cleaner Production 125: 22-32, https://doi.org/10.1016/ j.jclepro.2016.03.127

Thomas C (2004) Effective use of data in waste strategy planning in the UK. International Solid Waste Association (ISWA) World Environment Congress, Rome, Italy. International Solid Waste Association, Vienna, Austria. See http://oro.open.ac. uk/3676/1/Effective use of data C.Thomas.pdf (accessed 06/03/2017). 
Vazquez-Rowe I, Golkowska K, Lebuf V et al. (2015) Environmental assessment of digestate treatment technologies using LCA methodology. Waste Management 43: 442-459, https://doi.org/ 10.1016/j.wasman.2015.05.007.

WDF (WasteDataFlow) (2017) WasteDataFlow. Department for Environment, Food and Rural Affairs, London, UK. See http://www.wastedataflow.org/htm/datasets.aspx (accessed 15/01/2017).

Weiland P (2010) Biogas production: current state and perspectives. Applied Microbiology and Biotechnology 85(4): 849-860, https://doi.org/10.1007/s00253-009-2246-7.

Whiting A and Azapagic A (2014) Life cycle environmental impacts of generating electricity and heat from biogas produced by anaerobic digestion. Energy 70: 181-193, https://doi.org/10.1016/ j.energy.2014.03.103.

Wrap (Waste and Resources Action Programme) (2012) Tackling Priority Materials in Northern Ireland. Final Report. Wrap, Banbury, UK. See http://www.wrapni.org.uk/sites/files/wrap/ NIStrategicPriorities-finalreportforweb_2.pdf (accessed 15/01/2017).

Yiridoe E, Gordon R and Brown B (2009) Nonmarket cobenefits and economic feasibility of on-farm biogas energy production. Energy Policy 37(3): 1170-1179.

Zhang C, Su H, Baeyens J and Tan T (2014) Reviewing the anaerobic digestion of food waste for biogas production. Renewable and Sustainable Energy Reviews 38: 383-392.

\section{How can you contribute?}

To discuss this paper, please email up to 500 words to the editor at journals@ice.org.uk. Your contribution will be forwarded to the author(s) for a reply and, if considered appropriate by the editorial board, it will be published as discussion in a future issue of the journal.

Proceedings journals rely entirely on contributions from the civil engineering profession (and allied disciplines).

Information about how to submit your paper online is available at www.icevirtuallibrary.com/page/authors, where you will also find detailed author guidelines. 